\title{
Moderní metody používané při diagnostice mostů
}

\section{Modern Methods Used in Bridge Diagnostics}

\author{
Michal Jankư*, Jiří Grošek \\ Centrum dopravního výzkumu, v. v. i.
}

\begin{abstract}
Abstrakt
Kvalitní dopravní infrastruktura je znakem dobře fungujícího národního hospodářství a potažmo vyspělosti celé společnosti. Za účelem zachování řádného stavu budov, mostů, silnic a dalších staveb je nezbytná jejich pravidelná údržba a kontrola skutečného stavu. Často platí, že pokud se podaří zachytit poruchu na počátku jejího vzniku, jsou náklady na její odstranění daleko nižší než po měsících až letech nekontrolované degradace. Lokalizovat poruchu včas, často znamená detekovat ji ještě dříve, než je viditelná pouhým okem. Klíčovým prostředkem ke zjištění skrytých defekti̊ jsou metody nedestruktivního testování. V článku jsou popsány vybrané nedestruktivní metody, jež lze použít při diagnostice mostních objektů. Tento př́spěvek byl prezentován $\mathrm{v}$ rámci XXIX. mezinárodní vědecké konference Soudního inženýrství ExFoS 2020.
\end{abstract}

Klíčová slova: diagnostika mostu, georadar, termografie, metoda pulseecho, dron.

\section{1. ÚVOD}

Hodnocení stavu mostů je komplexní činnost, při které je potřeba shromáždit maximum informací o konstrukci mostu. Prvním krokem je sběr podkladů a informací o historii konstrukce. Další součástí jsou prohlídky mostů (běžné, hlavní, mimořádné), jež přinášejí základní informace o stavu mostů. $\mathrm{Na}$ základě výsledku prohlídky může být doporučena oprava mostu případně diagnostický průzkum mostu pro přesnější stanovení stavu mostu a jednotlivých částí konstrukce. Součástí diagnostického průzkumu může být i zatěžovací zkouška a následný statický výpočet. Všechny tyto kroky slouží jako podklad pro stanovení následných opatření a/nebo k určení rozsahu opravy/rekonstrukce mostu [1].

Tradiční diagnostický průzkum prováděný na betonových mostech v České republice se v současnosti nejčastěji skládá z:

- vizuální prohlídky konstrukce - fotodokumentace a popis poruch, prrípadně zjištění jejich příčin,

\begin{abstract}
Good, well-functioning infrastructure signifies a well-run national economy and the overall state of development of the whole society. Buildings, bridges, roads, and other structures need to be regularly maintained if they are to last. In general, if a defect is detected early, the cost of its remediation is typically much lower than if it the structure is allowed to degrade for months or years. Early defect detection often means detecting one before it is visible to the naked eye. A key means of locating hidden defects are nondestructive testing methods. The paper describes selected non-destructive methods that can be used in the diagnosis of bridge structures. The paper was presented in the $29^{\text {th }}$ International Scientific Conference of Forensic Engineering ExFoS 2020.
\end{abstract}

Keywords: bridge diagnostics, ground-penetrating radar, thermography, pulse-echo method, drone.

- stanovení základních chemických vlastností betonu stanovení pH betonu, hloubky karbonatace a množství chloridových iontů,

- zjišt'ování kvality betonu - sklerometricky s upřesněním na jádrových vývrtech,

- stanovení pevnosti $\mathrm{v}$ tahu povrchových vrstev - pomocí odtrhové zkoušky,

- zjištění množství a polohy výztuže v ŽB konstrukcích dřive radiograficky, nyní spíše elektromagnetickou indukční metodou a stále častěji též pomocí georadaru, ověření tloušt'ky výztuže je prováděno pomocí sekaných sond,

- zjištění stavu předpínací výztuže - nejčastěji pomocí destruktivního odstranění betonové krycí vrstvy.

Díky rozvoji v oblasti měřicí techniky v posledních letech se stále častěji uplatňují i další nedestruktivní metody [2]. Některé $\mathrm{z}$ nich budou popsány $\mathrm{v}$ následující kapitole. 


\section{DIAGNOSTICKÉ METODY}

\subsection{Georadar}

Georadar, někdy též známý pod zkratkou GPR (Ground Penetrating Radar), je měřicí zařízení fungující na principu vysílání vysokofrekvenčních elektromagnetických impulzů do zkoumaného prostředí a následné registraci jejich zpětných odrazů.

V posledních letech se na trh dostávají nové moderní př́stroje, které jsou mnohem více uživatelsky př́ivětivé než předchozí generace georadarů. Tyto kompaktní př́ístroje jsou určeny především pro jednoduchou a rychlou lokalizaci výztuže v betonu. Lze provádět jak liniové, tak i plošné skeny s automatickým vyhodnocením polohy výztuže. Ke zjednodušení měření se na povrch konstrukce lepí papírové šablony s vyznačeným rastrem pojezdů ve dvou na sebe kolmých směrech. Zjištěnou výztuž si lze následně prohlédnout i ve $3 \mathrm{D}$ zobrazení. Pokud nedosahuje hustota vyztužení př́liš vysokých hodnot, lze lokalizovat i polohu druhé vrstvy výztuže či kabelových kanálků. Jako příklad lze uvést georadar GP8000 od švýcarské firmy Proceq (obr. 1), který je pomocí Wi-Fi propojený s tabletem iPad. Prostřednictvím tabletu lze nastavovat parametry měření nebo prohlížet naměřená data.

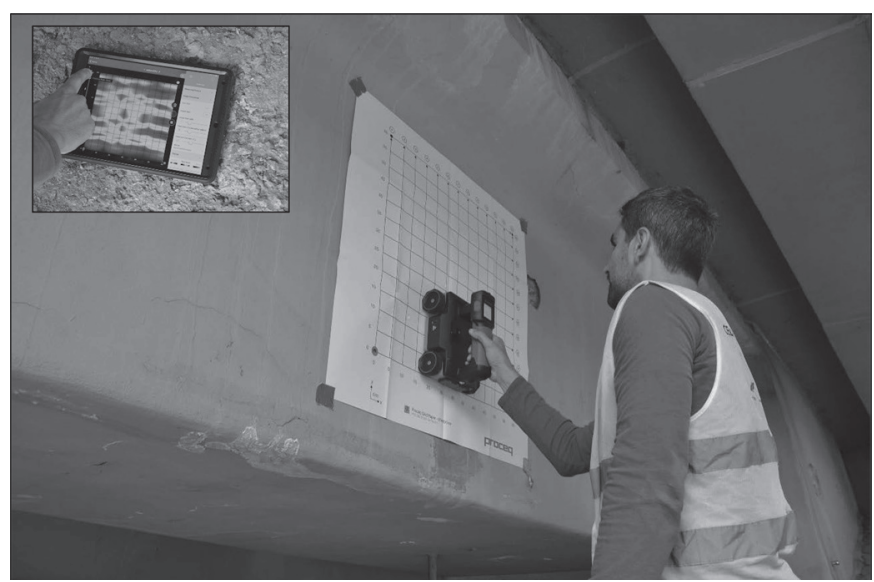

Obr. 1 Měrení předpjatého nosníku mostu georadarem Proceq. Fig. 1 Measurement of prestressed bridge girder by Proceq ground penetrating radar.

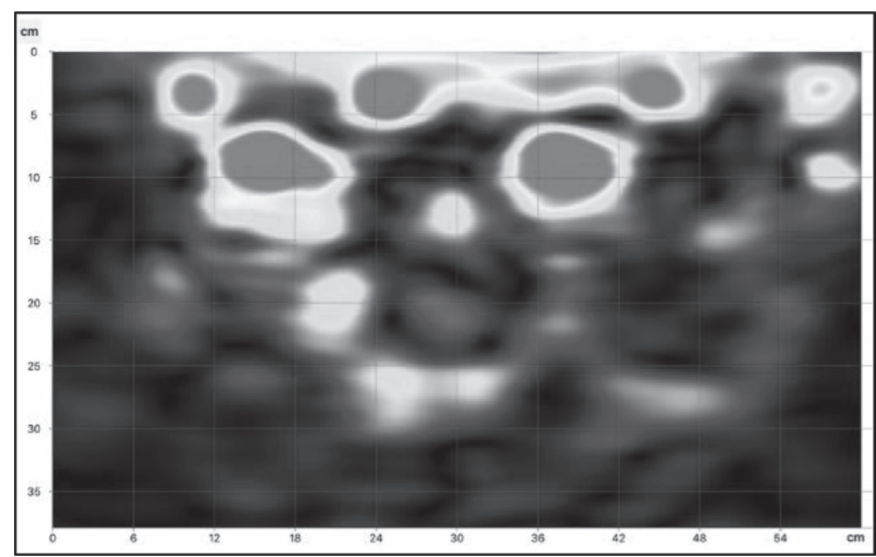

Obr. 2 Radargram (liniový sken): výztuž v horní vrstvě a kabelové kanálky pod ní.

Fig. 2 Radargram (line scan): reinforcement in the upper layer and cable ducts underneath.

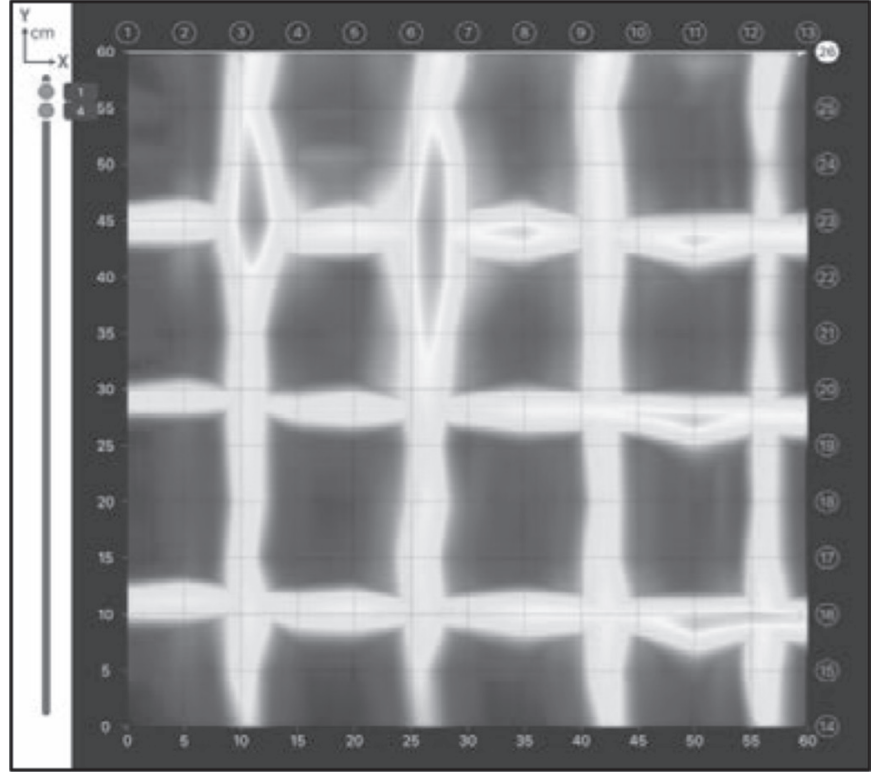

Obr. 3 Radargram (plošný sken): výztuž betonového mostu.

Fig. 3 Radargram (area scan): concrete bridge reinforcement.

Georadary bývají vybaveny jednou či více vysílacími anténami. Anténa generuje impulzy a vysílá je do zkoumané konstrukce. Pokud se v prostředí pod povrchem nachází nějaká diskontinuita, dochází k částečnému odražení impulzu zpět k povrchu, kde je tento signál zachycen přijímací anténou. Diskontinuita může být rozhraní mezi dvěma vrstvami s různými dielektrickými vlastnostmi, dutina nebo delaminace. Velmi dobře lze také použít georadar k vyhledání kovové výztuže v betonu.

Výrobci georadarů nabízí prŕístroje s různými druhy antén pracujících na frekvencích od $10 \mathrm{MHz}$ až po $10 \mathrm{GHz}$. S pomocí nízkofrekvenčních antén lze provádět měření do větších hloubek, ovšem s nižším rozlišením. Naopak vysokofrekvenční antény umožňují měřit ve vysokém rozlišení, ale s nižším hloubkovým dosahem. Pro inspekce betonových konstrukcí se běžně používají antény s centrální vysílací frekvencí nad $1 \mathrm{GHz}$.

Při měření georadarem je důležitý pohyb anténou, během něhož anténa opakovaně vysílá signál do zkoumané konstrukce. Podle požadované přesnosti měření lze nastavit počet skenů na jednotku délky, v př́ípadě betonových konstrukcí je obvykle používána četnost 1-10 skenů/cm. Intenzita odražené vlny je zaznamenávána $\mathrm{v}$ diskrétních časových okamžicích. Výsledný záznam z měření se nazývá radargram (obr. 2). Osa x obvykle odpovídá vzdálenosti, osa y představuje čas průchodu elektromagnetického signálu prostředím. Pro lepší přehlednost se tento čas převádí na hloubku pomocí známé (nebo odhadnuté) rychlosti šíření signálu v materiálu. $\mathrm{V}$ př́padě použití papírové šablony s vyznačeným rastrem pojezdů vytvoří př́stroj po změření všech linií automaticky plošný sken (obr. 3).

\subsection{Ultrazvuková pulse-echo metoda}

Základem metody pulse-echo je vysílání mechanických impulzů do zkoumaného prvku. Na rozdíl od georadaru, je však nutný přímý kontakt mezi měřicí sondou a povrchem zkoumané konstrukce. UZ sondu je tedy nutné postupně $\mathrm{k}$ povrchu přikládat na rozdíl od georadaru, kterým se po konstrukci pohybuje. Metoda pulseecho je určena především k lokalizaci vnitřních vad či rozhraní 

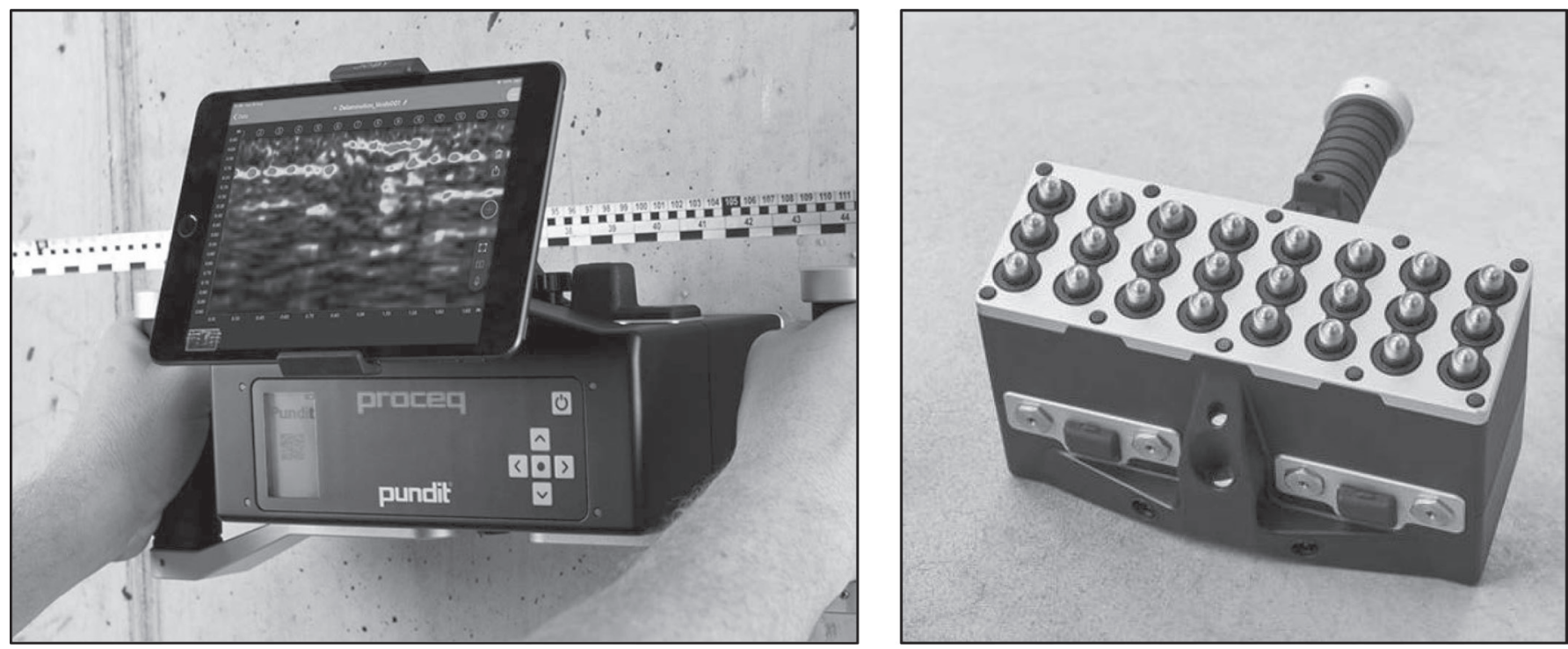

Obr. 4 Ultrazvukový pulse-echo přistroj Pundit PD8000 [3].

Fig. 4 Ultrasound pulse-echo instrument Pundit PD8000 [3].
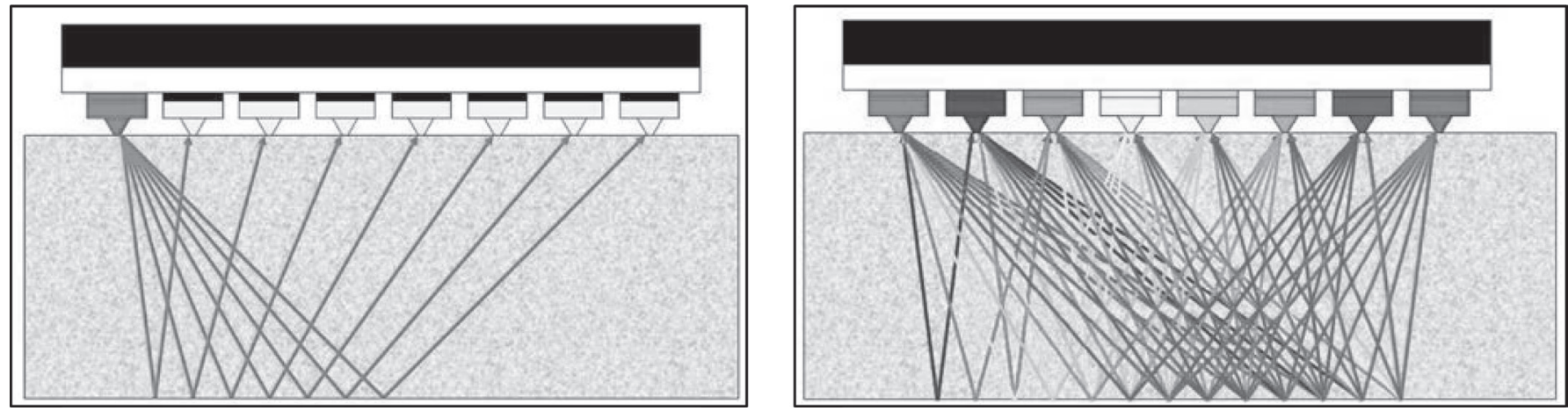

Obr. 5 Schéma funkce ultrazvukové pulse-echo sondy přistroje Pundit PD8000 [3].

Fig. 5 Functional diagram of the ultrasonic pulse-echo probe Pundit PD8000 [3].

materiálů. Pulse-echo sonda vysílá prostřednictvím budiče impulsy do zkoumané konstrukce, narazí-li impuls při svém prostupu materiálem na hranici mezi dvěma prostředími s různou akustickou impedancí, dochází $\mathrm{k}$ jeho částečnému odrazu zpět. Na povrchu je pak odražený impuls zaznamenán prostřednictvím snímače. Z naměřeného času průchodu signálu a rychlosti šíření impulzu v materiálu stanovené při kalibračním měření lze určit hloubky vnitřních rozhraní. Akustické vlny mohou, na rozdíl od elektromagnetických, prostupovat kovem. Díky tomu lze do určité míry kontrolovat i zainjektování kabelových kanálků.

Jako př́klad lze uvést přístroj Pundit PD8000 (obr. 4) od firmy Proceq. Měřicí zařízení se skládá z tabletu a z osmikanálové sondy. Při měření vždy jeden kanál vysílá impulzy, zatímco ostatní kanály slouží jako přijímače (obr. 5 vlevo). Takto se postupně během
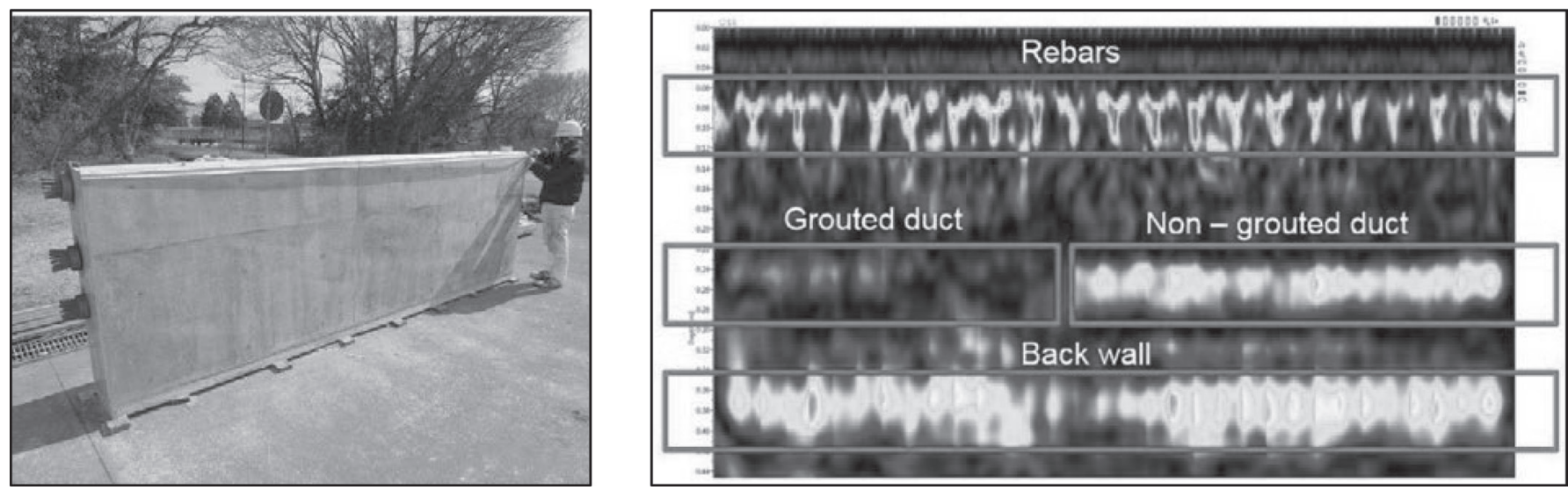

Obr. 6 Zkušební blok a záznam z ultrazvukového pulse-echo měření [3].

Fig. 6 Test block and ultrasonic pulse-echo measurement scan [3]. 
chvíle vystřídají všechny kanály (obr. 5 vpravo). Výsledkem je krátký liniový sken. Sondu lze postupně přikládat ke konstrukci, přičemž UZ př́stroj automaticky spojuje jednotlivé skeny za sebou a vykresluje řez konstrukcí na obrazovku tabletu.

Každý jednotlivý budič/snímač má vlastní nezávislý přítlak, díky čemuž je zaručen dokonalý kontakt s měřeným povrchem, lze tak provádět měření i na hrubém betonu. Hlavní aplikace této metody je lokalizace dutin či poruch a měření tloušt'ky betonových prvků. Na obr. 6 vpravo je ukázka z měření na zkušebním betonovém bloku. Nejblíže povrchu se podařilo lokalizovat ocelovou výztuž. Pod ní se nacházel kabelový kanálek, který byl ovšem zainjektován jen z jedné poloviny. UZ pulse-echo př́ístroj dokázal správně identifikovat nezainjektovanou část kanálku. Ve spodní části záznamu je odraz od zadní stěny zkušebního bloku.

\subsection{Infračervená termografie}

Infračervená termografie je založená na detekci záření objektů v infračerveném (IR) spektru vlnových délek. Zařízení, které detekuje a skládá 2D obraz IR záŕení se obecně nazývá infračervená kamera, nebo infračervená termografická kamera, zkráceně termokamera. Výsledkem záznamu termokamery je obraz odpovídající intenzitě tepelného vyzařování snímaného objektu. Tento záznam se nazývá termogram a je obrazem rozložení povrchové teploty tělesa.

Povrchová teplota zkoumaných objektů - mostů se mění v závislosti na okolní teplotě, intenzitě slunečního záření a na materiálových vlastnostech. Tři hlavní faktory, které ovlivňují šíření tepla $\mathrm{v}$ materiálu, jsou tepelná vodivost, měrná tepelná kapacita a hustota. Za běžných podmínek lze beton pro účely určení teplotních vlastností považovat za homogenní materiál. Pokud se však pod povrchem nachází nějaká dutina, dochází $\mathrm{k}$ přerušení kontinuity materiálu, čímž se mění charakteristiky přenosu tepla. Je-li defekt dostatečně velký a blízký povrchu, ovlivňuje i přenos tepla, což se projeví jako lokální změna povrchové teploty, kterou lze zaznamenat pomocí termokamery.

Během dne dochází obvykle ke kolísání mezi denní a noční teplotou. Na tyto změny reaguje i konstrukce. Vlivem dopadajícího slunečního záření a/nebo vzrůstající okolní teploty se nejprve ohřívá povrch objektu, od kterého se teplo dále šírí vedením

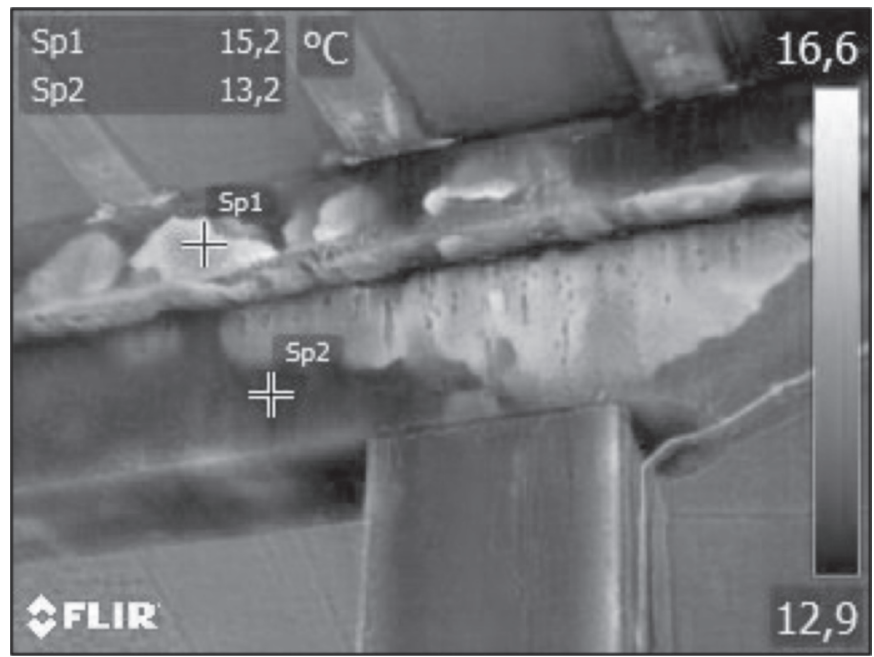

Obr. 7 Termogram betonového mostu.

Fig. 7 Thermogram of concrete bridge. hlouběji do konstrukce. Pokud naopak dojde ke snížení okolní teploty (v noci), konstrukce se ochlazuje a teplo je vedeno opačným směrem. V př́ipadě, že se pod povrchem konstrukce nachází nějaká dutina (např. delaminace), působí vzduch, který se v ní nachází jako „izolace“, jež omezuje přenos tepla. Tato porucha způsobuje, že se při změně teploty povrch nad ní zahřívá více než okolí bez závad. Při oteplování konstrukce lze proto očekávat, že oblasti nad dutinou budou teplejší než okolní nepoškozený beton - vzniká tzv. pozitivní teplotní kontrast (obr. 7). Při ochlazování konstrukce nastává opak, kdy v těchto místech dochází k rychlejšímu odvodu tepla, a proto se budou tyto oblasti na pořízených termogramech jevit jako chladnější - negativní teplotní kontrast (obr. 8).

Infračervenou termografii lze za vhodných podmínek použít při zjišt'ování plošných poruch na betonových konstrukcích. Tyto poruchy bývají způsobeny například korozí ocelové výztuže. Vznikající korozní produkty mají totiž podstatně větší objem než původní kov. Jejich tvorba má za následek zvýšený tlak na betonovou krycí vrstvu. S přibýváním korozních produktů se tento tlak zvyšuje až do vzniku trhlin a delaminací betonové krycí vrstvy nebo odlupování menších částí pouze nad pruty výztuží. Následně může dojít až k úplnému odtržení částí betonu. Čím je menší hloubka uložení výztuže pod povrchem, nižší kvalita krycí vrstvy a nepř́znivější prostředí, tím dříve hrozí vznik koroze. Tento problém se týká především starších mostů postavených za minulého režimu.

Další možnost využití infračervené termografie nastává při kontrole sanačních vrstev nejen betonových mostů. Pokud dojde k oddělení sanační vrstvy od podkladu, dutina způsobuje z hlediska termografického zkoušení stejný efekt jako v prŕípadě delaminace od korodující výztuže a lze ji tedy za vhodných podmínek lokalizovat pomocí termokamery (obr. 9).

Termografickou metodu lze také použít ke zjišt’ování prŕitomnosti vody $\mathrm{v}$ betonové konstrukci mostu. Při měření se vychází ze skutečnosti, že kapalina při vypařování odebírá teplo svému okolí. Pomocí termokamery tak lze odhalit oblasti s př́tomností vlhkosti, která nemusí být pouhým okem na první pohled zřejmá. Na obr. 10 je patrné zatékání po povrchu betonové nosníku pravděpodobně porušenou izolací.

Použití infračervené termografie se doporučuje provádět podle certifikované metodiky Ministerstva dopravy ČR z roku 2018 [4].

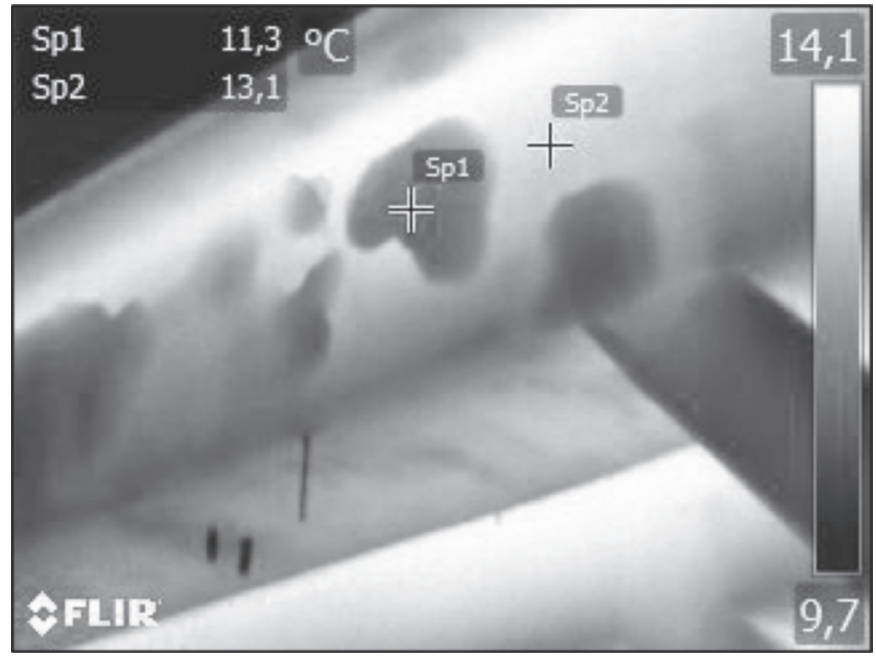

Obr. 8 Termogram betonového mostu.

Fig. 8 Thermogram of concrete bridge. 


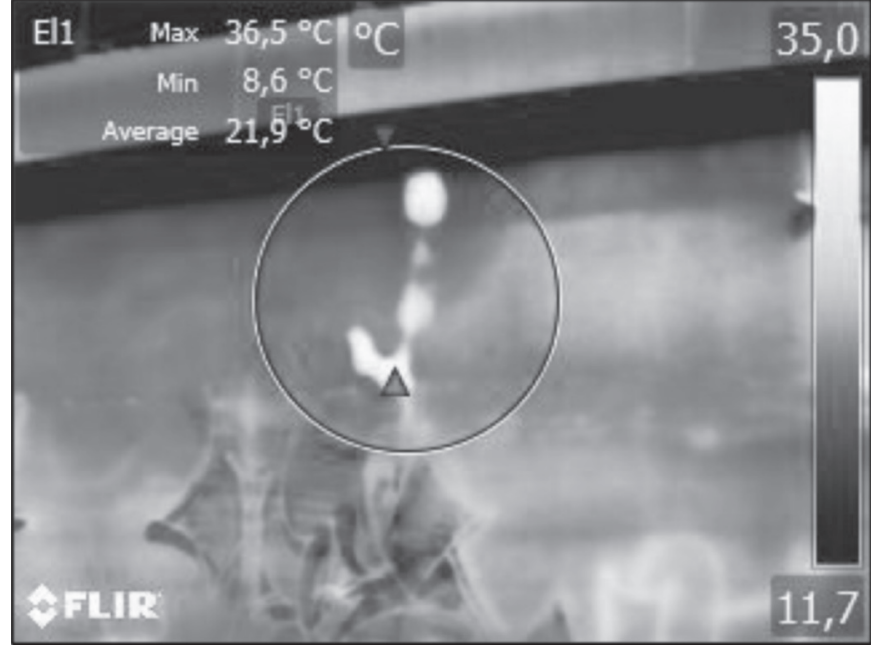

Obr. 9 Porucha sanace na opěre mostu.

Fig. 9 Failure of remediation at the bridge support.

\section{POUŽITÍ DRONU゚ PRO PRŮZKUM MOSTŮ}

V posledních letech dochází k velkému rozvoji dronů a spolu s ním se objevují i nové možnosti jejich využití. Jednou z řady možností jsou i prohlídky mostních konstrukcí. Dříve bylo pro kontrolu stavu vyšších mostů nutné použít vysokozdvižnou plošinu nebo tzv. mostní prohlížečku. Tato zařízení lze v mnoha príípadech nahradit drony. S jejich pomocí lze efektivně prozkoumat špatně přistupné části mostů. Navíc vychází použití dronů cenově i časově výhodněji ve srovnání s pronájmem mostní prohlížečky. Některé typy dronů jsou dokonce vybaveny „klecí“, která je chrání proti poškození při střetu s překážkou (kritické jsou především listy vrtulí). Dron Flyability Elios 2 (obr. 11) je navržen pro létání ve vnitřních prostorech, kromě digitální kamery je vybaven i termokamerou,



Obr. 11 Dron Flyability Elios 2 [5].

Fig. 11 Drone Flyability Elios 2 [5].

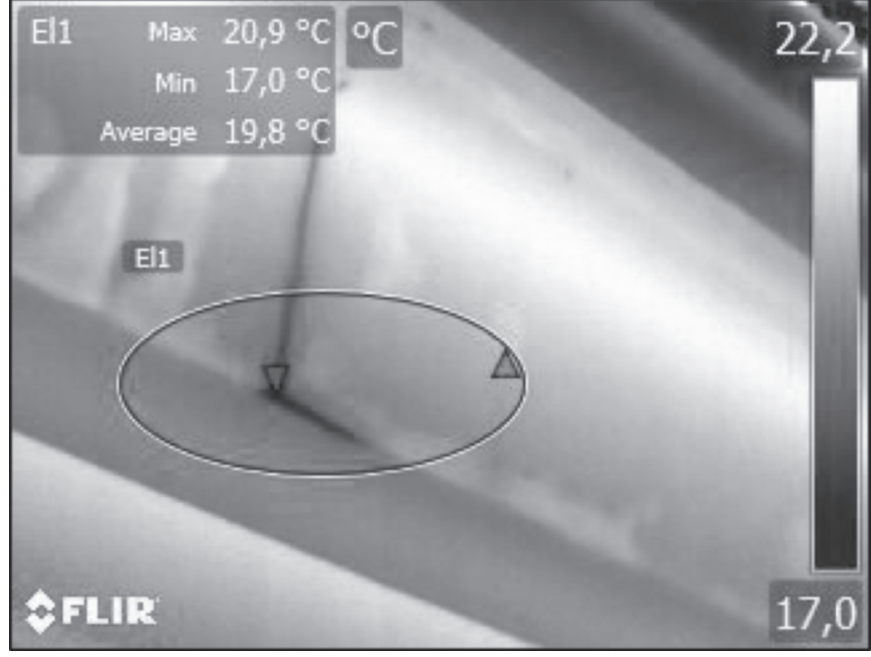

Obr. 10 Zatékání po povrchu nosniku.

Fig. 10 Leaking on the beam surface.

výkonným přisvícením a různými senzory, které usnadňují ovládání dronu při letu.

Pokud ovšem člověk létá s jakýmkoliv dronem venku, stane se účastníkem leteckého provozu a musí dodržovat určitá pravidla. Navíc uživatel dronu, který ho provozuje ke komerčním či výzkumným účelům, musí být zaregistrovaný na Úřadě pro civilní létání (ÚCL) a zároveň zde získat př́islušnou licenci. I přes to, že se při prohlídce mostu pohybuje dron z větší části pod mostem (obr. 12), je potřeba před každým letem s dostatečným předstihem vyjednat povolení $\mathrm{k}$ letu na ÚCL. Létání je třeba provozovat $\mathrm{v}$ bezpečné vzdálenosti od lidí. Nelze také létat $\mathrm{v}$ zakázaném leteckém prostoru neboli bezletové zóně. Př̀i létání s drony je také nezbytné, aby měl pilot dronu stroj vždy na dohled očí.

\section{ZÁVĚR}

I přesto, že jsou tradiční diagnostické postupy stále hojně použivány, vzrůstá postupně důvěra v nové nedestruktivní metody.

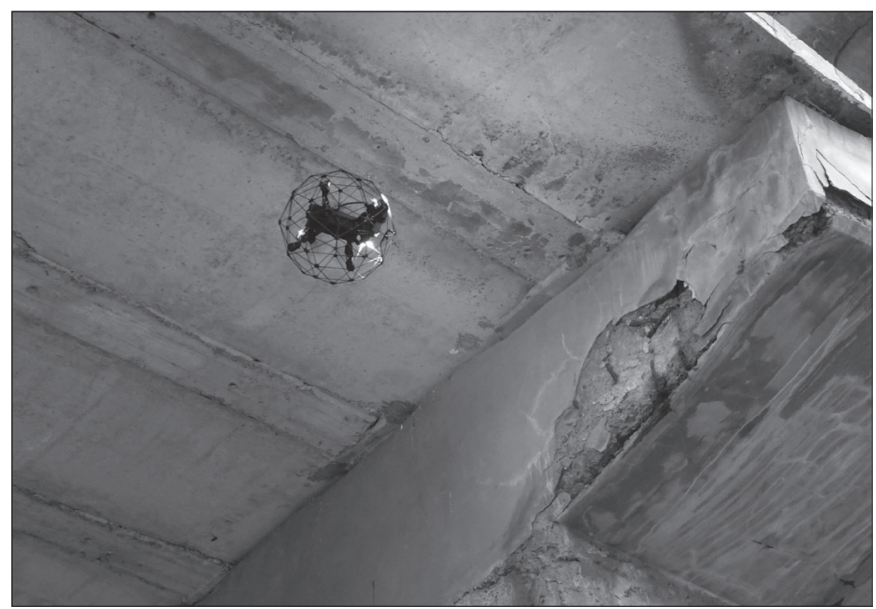

Obr. 12 Dron při prìzkumu betonového mostu. Fig. 12 Drone while exploring a concrete bridge. 
Autoři př́íspěvku věří, že jejich hojnější využití je jen otázkou času. Výše popsané metody pro diagnostiku betonových mostů lze obecně využít i pro většinu ostatních betonových konstrukcí.

\section{PODĚKOVÁNÍ}

Tento příspěvek byl vytvořen za finanční podpory Ministerstva školství, mládeže a tělovýchovy v rámci programu Národní program udržitelnosti I, projektu Dopravní VaV centrum (LO1610) na výzkumné infrastruktuře pořízené z Operačního programu Výzkum a vývoj pro inovace (CZ.1.05/2.1.00/03.0064).

\section{LITERATURA}

[1] TP 72. Diagnostický průzkum mostů PK. Praha: Ministerstvo dopravy České republiky, 2009.

[2] JANKŮ, M., CIKRLE, P., GROŠEK, J., ANTON, O., STRYK, J. Comparison of infrared thermography, ground-penetrating radar and ultrasonic pulse echo for detecting delaminations in concrete bridges. Construction and Building Materials. 2019, 225, 1098-1111. DOI: 10.1016/j.conbuildmat.2019.07.320. ISSN 0950-0618. Dostupné také z: https://linkinghub.elsevier.com/ retrieve/pii/S0950061819319944
[3] PROCEQ: Pundit ultrasonic pulse velocity and pulse echo tomography [online]. [cit. 2020-01-09]. Dostupné z: https://www. proceq.com/compare/pundit-ultrasonic-pulse-velocity-and-pulseecho-testing/.

[4] JANKŮ, M., STRYK, J. Uplatněni termografie při diagnostice objektů dopravní infrastruktury: Certifikovaná metodika. Brno: Centrum dopravního výzkumu, v. v. i., 2018.

ISBN 978-80-88074-34-2. Dostupné z: https://www.cdv.cz/ metodiky/.

[5] FLYABILITY: Elios 2 [online]. [cit. 2020-01-09]. Dostupné z: https://www.flyability.com/elios-2.

[6] JANKU゚, M., GROŠEK, J.. Moderní metody používané při diagnostice mostů. In: Sbornik př́spěvků konference Expert Forensic Science Brno 2020. Brno: Vysoké učení technické v Brně, Ústav soudního inženýrství, 2020, s. 276-283. ISBN 978-80-214-5829-1.

\section{Správná citace:}

JANKŮ, M., GROŠEK, J. Moderní metody používané při diagnostice mostů. Soudní inženýrství, 2020, 31(2), 31-36.

DOI: http://dx.doi.org./10.13164/SI.2020.2.31. ISSN 1211-443X. 